\title{
Postoperative nausea and vomiting after mastoidectomy with tympanoplasty: a comparison between TIVA with propofol-remifentanil and balanced anesthesia with sevoflurane-remifentanil
}

\author{
Dae Wook Lee, Hyung Gon Lee, Chang Young Jeong, Seong Wook Jeong, and Seong Heon Lee \\ Department of Anesthesiology and Pain Medicine, Chonnam National University, Medical School, Gwangju, Korea
}

Background: There is growing interest in the anesthetic approach using total intravenous anesthesia (TIVA) with propofol and remifentanil for the prevention of postoperative nausea and vomiting (PONV). The aim of this study was to compare between the two anesthetic techniques for preventing PONV in the patients undergoing mastoidectomy with tympanoplasty.

Methods: After obtaining informed consent, 62 patients aged between 20 to 60 years undergoing elective mastoidectomy and tympanoplasty were randomized into two equal study groups: group P/R $(n=31)$ included patients undergoing TIVA with propofol and remifentanil, and group S/R $(n=31)$ included patients undergoing balanced anesthesia with sevoflurane and remifentanil. The incidences of PONV and complete response (no PONV, no rescue) were assessed at 1 and $24 \mathrm{~h}$ after surgery, using the Rhodes Index. Also, the usage of rescue antiemetics and pain intensity were recorded.

Results: The Rhodes Index including the occurrence score, distress score and experience score was significantly lower in the $\mathrm{P} / \mathrm{R}$ group compared to that in the $\mathrm{S} / \mathrm{R}$ group during the study period $(\mathrm{P}<0.05)$, and the incidence of complete response was significantly higher in the $\mathrm{P} / \mathrm{R}$ group compared to that in the S/R group, during the first $24 \mathrm{~h}$ after surgery. 4 patients in the $\mathrm{S} / \mathrm{R}$ group requested antiemetics during the first $1 \mathrm{~h}$ after surgery. There were no significant differences in pain intensity among groups.

Conclusions: Compared to balanced anesthesia with sevoflurane and remifentanil, TIVA with propofol and remifentanil was followed by significantly lower incidence and severity of PONV. (Korean J Anesthesiol 2011; 61: 399-404)

Key Words: Anesthesia, Postoperative nausea and vomiting, Propofol, Sevoflurane, Tympanoplasty.

Received: April 26, 2011. Accepted: May 10, 2011.

Corresponding author: Hyung Gon Lee, M.D., Ph.D., Department of Anesthesiology and Pain Medicine, Chonnam National University, Medical School, 671, Jebong-no, Dong-gu, Gwangju 501-757, Korea. Tel: 82-62-220-6893, Fax: 82-62-232-6294, E-mail: leehg@chonnam.ac.kr (c) This is an open-access article distributed under the terms of the Creative Commons Attribution Non-Commercial License (http:// creativecommons.org/licenses/by-nc/3.0/), which permits unrestricted non-commercial use, distribution, and reproduction in any medium, provided the original work is properly cited. 


\section{Introduction}

Postoperative nausea and vomiting (PONV) is a common, unpleasant, and exhausting complication that may occur after surgery and can lead to increased recovery room time, potential hospital admission, and increased total health care costs [1]. Expert anesthesiologists have ranked PONV during induction as second among 33 clinical anesthesia outcomes in frequency and importance [2]. PONV is one of the most frequently encountered complaints after middle ear surgery. It has been reported that $50-80 \%$ of the patients who undergo middle ear surgery experience PONV [3-5]. This incidence may justify the use of prophylactic antiemetics for the prevention of PONV after middle ear surgery. Numerous antiemetics, such as $5-\mathrm{HT}_{3}$ antagonists, dopamine receptor antagonists, and antihistamine drugs have been studied for the prevention of PONV after middle ear surgery. However, each of these treatments is associated with critical limiting factors and none of the available antiemetics is entirely effective after middle ear surgery in adult patients [6].

Anesthesia-related factors that affect the incidence of PONV include intraoperative anesthetic drugs and techniques [7]. Previous study has shown that volatile anesthetics were the leading cause of early postoperative vomiting and the proemetic effect was larger than other risk factors $[8,9]$. Therefore, the most logical approach for prevention of PONV would be the omission of volatile anesthetics and nitrous oxide using a total intravenous anesthesia with propofol [9].

Propofol (2,6-diisopropylphenol), an intravenous hypnotic, has been a popular choice for both induction and maintenance of general anesthesia owing to its rapid onset, short duration of action and low incidence of PONV. A total intravenous anesthesia (TIVA) regimen with remifentanil and propofol is a useful anesthetic technique, effectively controlling responses to tracheal intubation and intense surgical stimulation, while allowing for rapid emergence from anesthesia without prolonged respiratory depression $[10,11]$.

There is growing interest in the anesthetic approach using TIVA with propofol and remifentanil for the prevention of postoperative nausea and vomiting. A recent study demonstrated that compared to volatile anesthetics, TIVA resulted in a significantly lower incidence of PONV in day-case surgery [1214]. However, there are no previous reports on the anesthetic approach using TIVA with propofol and remifentanil for the prevention of postoperative nausea and vomiting after middle ear surgery.

The aim of this study was to compare between the two anesthetic techniques of TIVA with propofol-remifentanil and balanced anesthesia with sevoflurane-remifentanil for preventing PONV in the adult patients undergoing mastoidectomy with tympanoplasty.

\section{Materials and Methods}

After obtaining approval from the institutional review board and informed consent of subjects, the study was prospectively carried out in 62 patients, ASA (American Society of Anesthesiologists) physical status I or II aged between 20 to 60 years, who underwent general anesthesia for tympanoplasty and mastoidectomy. Patients with gastrointestinal disease, a history of motion sickness, or a previous episode of PONV, and those who had received any opioid, steroid, or antiemetic medication within $24 \mathrm{~h}$ before surgery, and those who were pregnant or menstruating were excluded.

No premedication was administered before the induction. Patients were transferred to the operating room where they were monitored continuously with electrocardiogram, pulse oximetry, non-invasive arterial pressure and Bispectral Index score (BIS) monitoring, inspiratory oxygen concentration $\left(\mathrm{FIO}_{2}\right)$ and end-tidal $\mathrm{CO}_{2}\left(\mathrm{EtCO}_{2}\right)$. Also, nasopharyngeal temperature was monitored and maintained with $36.5 \pm 1{ }^{\circ} \mathrm{C}$ throughout surgery. Patients were randomly assigned, according to a computer-generated random number table, to receive one of the following two anesthetic techniques: general anesthesia using sevoflurane and remifentanil (S/R group) or total intravenous anesthesia with propofol-remifentanil ( $\mathrm{P} / \mathrm{R}$ group). Age, weight, height, volume of fluids during anesthesia and duration of surgery and anesthesia were recorded.

Before anesthesia induction, all patients breathed $100 \%$ oxygen for $5 \mathrm{~min}$ and received an intravenous (IV) fluid load of lactated Ringer's solution $5 \mathrm{ml} / \mathrm{kg}$. The infusions of propofol and remifentanil were prepared using Fresofol 2\% inj., 50 $\mathrm{ml}$ vial (Fresenius Kabi, Austria) and Ultiva ${ }^{\mathrm{TM}}$ inj., $1 \mathrm{mg}$ vial (GlaxoSmithKline, Belgium), respectively. Remifentanil $1 \mathrm{mg}$ was diluted into $50 \mathrm{ml}$ of normal saline ( $20 \mathrm{mg} / \mathrm{ml}$ solution). A commercial target controlled infusion (TCI) pump (Orchestra ${ }^{\circledR}$ Base Primea, Fresenius Vial, France) was used for the effectsite TCI of propofol and remifentanil. The pump used was the Marsh and colleagues [15] and Minto and colleagues [16] models for propofol and remifentanil, respectively.

The $\mathrm{P} / \mathrm{R}$ group received remifentanil to a target effect-site concentration (Ce) of $3 \mathrm{ng} / \mathrm{ml}$. When the intended target Ce of remifentanil was reached, TCI of propofol was then started at a target Ce of $3.5 \mathrm{mg} / \mathrm{ml}$. The drug infusions were continued until the patient fell asleep and tracheal intubation was facilitated by rocuronium $0.6 \mathrm{mg} / \mathrm{kg}$. The patients were mechanically ventilated with $50 \%$ oxygen and air to maintain $\mathrm{EtCO}_{2}$ between 30 and $35 \mathrm{mmHg}$, and anesthesia was maintained with continuous infusion of remifentanil and propofol infusion using TCI device according hemodynamic response and Bispectral 
Index (BIS) score. The target concentrations of propofol and remifentanil were adjusted in increments or decrements of 0.2 $\mathrm{ng} / \mathrm{ml}$ and $0.2 \mu \mathrm{g} / \mathrm{ml}$, respectively, every minute to maintain the BIS between 40 and 60 .

Patients assigned to the $\mathrm{S} / \mathrm{R}$ group received remifentanil to a target Ce of $3 \mathrm{ng} / \mathrm{ml}$ followed by propofol $2 \mathrm{mg} / \mathrm{kg}$ IV. After the loss of the eyelash reflex, the patients were intubated with endotracheal tube after administration of rocuronium $0.6 \mathrm{mg} /$ $\mathrm{kg}$. The patients were mechanically ventilated with $50 \%$ oxygen and air, and anesthesia was maintained with sevoflurane 1.0 to 3.0 vol\% and continuous remifentanil infusion using TCI device. At the end of surgery, glycopyrrolate $7 \mu \mathrm{g} / \mathrm{kg}$ and pyridostigmine $30 \mu \mathrm{g} / \mathrm{kg}$ were administered intravenously for the antagonism of residual neuromuscular blockade. A nasogastric tube was inserted to empty the stomach and it was removed before extubation of the tracheal tube. Pain intensity scores were measured with a visual analog scale (VAS) ranging from 0 (no pain) to 10 (the worst possible pain). First-line analgesic treatment was with ketorolac $30 \mathrm{mg}$ IV when the patient asked for an analgesic. If the patient did not respond to the initial treatment, pethidine $25 \mathrm{mg}$ IV followed as secondline treatment.

All episodes of PONV (nausea, retching, and vomiting) during the periods 0 to $1 \mathrm{~h}$ and 1 to $24 \mathrm{~h}$ after anesthesia were recorded by investigators who were unaware of the anesthetic technique used in each patient. Nausea was defined as the subjectively unpleasant sensation associated with awareness of the urge to vomit; retching was defined as the labored, spastic, rhythmic contraction of the respiratory muscles without expulsion of the gastric contents; and vomiting was defined as the forceful expulsion of gastric contents from the mouth [7]. At the end of each observation period, patients evaluated the severity of PONV using the Rhodes Index [17] (Table 1). Complete response (i.e., emesis-free) was defined as no PONV and no need for another rescue antiemetic medication. Rescue antiemetics were administered for active nausea and vomiting defined above. First-line rescue treatment was with metoclopramide $10 \mathrm{mg}$ IV. If the patient did not respond to the initial treatment, ondansetron $4 \mathrm{mg}$ IV followed as second-line treatment.

Based on previous studies [3-5], the predicted incidence of PONV in this study was in the region of 70 percent. It was decided that a $30 \%$ reduction in the incidence of PONV in the $\mathrm{P} / \mathrm{R}$ group would be clinically relevant. The $\alpha$ error was set at 0.05 (two-sided) and the $\beta$ error at 0.02 (power $=0.8$ ). This analysis showed that 28 patients were necessary in each group. We assumed a dropout rate of $10 \%$, and so we increased the sample size to 31 patients per group. Statistical analyses were performed using SPSS software (version 15.0, SPSS Inc., IL, USA). Analysis of variance with Bonferroni's correction, the $\chi^{2}$ test, Fisher's exact test, or the Mann-Whitney $U$-test was performed where appropriate. A $\mathrm{P}$ value of $<0.05$ was considered significant. Values were expressed as means (SD), or number of patients (\%).

\section{Results}

No statistically significant differences were observed with respect to age, body weight, height, sex ratio, fluid volume during anesthesia, duration of anesthesia and surgery between the two groups (Table 2).

The Rhodes Index was significantly lower in the $\mathrm{P} / \mathrm{R}$ group

Table 1. Rhodes Index of Nausea, Vomiting, and Retching (RINVR)

\begin{tabular}{|c|c|c|c|c|c|}
\hline 1. In the last ( ) hours, I threw up $\circ \circ$ times. & $\begin{array}{l}7 \text { or more } \\
(4)\end{array}$ & $\begin{array}{c}5-6 \\
(3)\end{array}$ & $\begin{array}{c}3-4 \\
(2)\end{array}$ & $\begin{array}{c}1-2 \\
(1)\end{array}$ & $\begin{array}{l}\text { I did not throw up } \\
(0)\end{array}$ \\
\hline $\begin{array}{l}\text { 2. In the last ( ) hours, from retching and } \\
\text { dry heaves, I have felt } \circ \circ \text { distress. }\end{array}$ & $\begin{array}{l}\text { No } \\
(0)\end{array}$ & $\begin{array}{l}\text { Mild } \\
(1)\end{array}$ & $\begin{array}{l}\text { Moderate } \\
\text { (2) }\end{array}$ & $\begin{array}{c}\text { Great } \\
(3)\end{array}$ & $\begin{array}{l}\text { Severe } \\
\text { (4) }\end{array}$ \\
\hline $\begin{array}{l}\text { 3. In the last ( ) hours, from vomiting or } \\
\text { throwing up, I have felt } \circ \circ \text { distress. }\end{array}$ & $\begin{array}{l}\text { Severe } \\
\text { (4) }\end{array}$ & $\begin{array}{c}\text { Great } \\
(3)\end{array}$ & $\begin{array}{l}\text { Moderate } \\
\text { (2) }\end{array}$ & $\begin{array}{l}\text { Mild } \\
\text { (1) }\end{array}$ & $\begin{array}{l}\text { No } \\
(0)\end{array}$ \\
\hline $\begin{array}{l}\text { 4. In the last ( ) hours, I have felt nauseated } \\
\text { or sick to my stomach. }\end{array}$ & $\begin{array}{l}\text { Not at all } \\
(0)\end{array}$ & $\begin{array}{l}1 \text { hour or less } \\
\text { (1) }\end{array}$ & $\begin{array}{c}2-3 \text { hours } \\
\text { (2) }\end{array}$ & $\begin{array}{c}4-6 \text { hours } \\
\text { (3) }\end{array}$ & $\begin{array}{c}\text { More than } 6 \text { hours } \\
\text { (4) }\end{array}$ \\
\hline $\begin{array}{l}\text { 5. In the last ( ) hours, from nausea/ } \\
\text { sickness to my stomach, I have felt } \\
\text { o distress. }\end{array}$ & $\begin{array}{l}\text { No } \\
(0)\end{array}$ & $\begin{array}{l}\text { Mild } \\
\text { (1) }\end{array}$ & $\begin{array}{l}\text { Moderate } \\
\text { (2) }\end{array}$ & $\begin{array}{c}\text { Great } \\
(3)\end{array}$ & $\begin{array}{l}\text { Severe } \\
\text { (4) }\end{array}$ \\
\hline $\begin{array}{l}\text { 6. In the last ( ) hours, each time I threw up, } \\
\text { I produced a ○০ amount. }\end{array}$ & $\begin{array}{c}\text { Very large } \\
\text { (3 cups or more) } \\
(4)\end{array}$ & $\begin{array}{c}\text { Large } \\
(2-3 \text { cups }) \\
\text { (3) }\end{array}$ & $\begin{array}{c}\text { Moderate } \\
(1 / 2-2 \text { cups }) \\
\text { (2) }\end{array}$ & $\begin{array}{c}\text { Small } \\
\text { (up to } 1 / 2 \text { cups) } \\
\text { (1) }\end{array}$ & $\begin{array}{l}\text { I did not } \\
\text { throw up } \\
\quad(0)\end{array}$ \\
\hline $\begin{array}{l}\text { 7. In the last ( ) hours, I have felt nauseated } \\
\text { or sick to my stomach ○० times. }\end{array}$ & $\begin{array}{l}7 \text { or more } \\
(4)\end{array}$ & $\begin{array}{c}5-6 \\
(3)\end{array}$ & $\begin{array}{c}3-4 \\
(2)\end{array}$ & $\begin{array}{c}1-2 \\
(1)\end{array}$ & $\begin{array}{l}\text { No } \\
(0)\end{array}$ \\
\hline $\begin{array}{l}\text { 8. In the last ( ) hours, I have had periods of } \\
\text { retching or dry heaves without bringing } \\
\text { anything up ○০ times. }\end{array}$ & $\begin{array}{l}\text { No } \\
(0)\end{array}$ & $\begin{array}{l}1-2 \\
(1)\end{array}$ & $\begin{array}{l}3-4 \\
(2)\end{array}$ & $\begin{array}{c}5-6 \\
(3)\end{array}$ & $\begin{array}{l}7 \text { or more } \\
(4)\end{array}$ \\
\hline
\end{tabular}

Total experience score: sum of all scores, total occurrence score: $1+4+6+7+8$, total distress score: $2+3+5$. 
Table 2. Patient Characteristics

\begin{tabular}{lccc}
\hline & $\begin{array}{c}\text { S/R group } \\
(\mathrm{n}=31)\end{array}$ & $\begin{array}{c}\text { P/R group } \\
(\mathrm{n}=31)\end{array}$ & P value \\
\hline Sex (M/F) & $13 / 18$ & $14 / 17$ & 0.802 \\
Age (yrs) & $49.1 \pm 11.1$ & $47.3 \pm 13.0$ & 0.773 \\
Weight (kg) & $60.3 \pm 12.8$ & $61.3 \pm 8.5$ & 0.438 \\
Height (cm) & $162.5 \pm 15.4$ & $161.5 \pm 13.8$ & 0.441 \\
Volume of fluids during & $21.2 \pm 7.3$ & $19.2 \pm 5.0$ & 0.153 \\
$\quad$ anesthesia (ml/kg) & & & \\
Duration of operation (min) & $133.4 \pm 26.2$ & $130.0 \pm 28.6$ & 0.224 \\
Duration of anesthesia (min) & $169.2 \pm 25.0$ & $166.8 \pm 28.4$ & 0.493 \\
\hline
\end{tabular}

The values are shown as means \pm SD or number of patients. There were no significant differences between groups.

Table 3. Rhodes Index of Nausea, Vomiting and Retching (RINVR) and Incidence of Complete Response

\begin{tabular}{lccc}
\hline & $\begin{array}{c}\text { S/R group } \\
(\mathrm{n}=31)\end{array}$ & $\begin{array}{c}\text { P/R group } \\
(\mathrm{n}=31)\end{array}$ & P value \\
\hline During 0-1 hr & & & \\
$\quad$ Complete response & $19(61.3 \%)$ & $30(96.8 \%)^{*}$ & 0.001 \\
Occurrence score & $1.00 \pm 1.57$ & $0.06 \pm 0.36^{*}$ & 0.001 \\
Distress score & $0.87 \pm 1.41$ & $0.06 \pm 0.36^{*}$ & 0.001 \\
Experience score & $1.87 \pm 2.94$ & $0.13 \pm 0.72^{*}$ & 0.001 \\
Rescue antiemetics & $4(12.9 \%)$ & $0(0 \%)$ & 0.078 \\
During 1-24 hr & & & \\
Complete response & $25(80.6 \%)$ & $30(96.8 \%)^{*}$ & 0.047 \\
Occurrence score & $0.81 \pm 2.01$ & $0.13 \pm 0.72^{*}$ & 0.048 \\
Distress score & $0.45 \pm 1.09$ & $0.06 \pm 0.36^{*}$ & 0.047 \\
Experience score & $1.26 \pm 3.09$ & $0.19 \pm 1.08^{*}$ & 0.049 \\
Rescue antiemetics & $0(0 \%)$ & $0(0 \%)$ & 0.317 \\
\hline
\end{tabular}

The values are shown as means \pm SD or number of patients. $* \mathrm{P}<0.05$ between two groups.

compared to that in the S/R group during the first $24 \mathrm{hrs}$ after surgery (Table 3 ). The Rhodes Index including the occurrence score and distress score and experience score was significantly lower in the $\mathrm{P} / \mathrm{R}$ group $(0.06,0.06$ and 0.13 , respectively) compared to that in the S/R group (1.00, 0.87 and 1.87, respectively), during the first $1 \mathrm{~h}$ after surgery. Also, during $1-24 \mathrm{~h}$ after surgery, the Rhodes Index was significantly lower in the P/ $\mathrm{R}$ group $(0.13,0.06$ and 0.19 , respectively) compared to that in the S/R group (0.81, 0.45 and 1.26, respectively). The incidence of complete response was significantly higher in the $\mathrm{P} / \mathrm{R}$ group compared to that in the S/R group, during the first $24 \mathrm{~h}$ after surgery (Table 3). The incidence of complete response in the $\mathrm{P} /$ $\mathrm{R}$ and S/R groups was: $9797.5 \%$ and $61 \%$, respectively, during the first $1 \mathrm{~h}$; and $97 \%$ and $81 \%$, respectively, during 1 to $24 \mathrm{~h}$ after surgery. 4 patients in the $\mathrm{S} / \mathrm{R}$ group requested antiemetics during the first $1 \mathrm{~h}$ after surgery (Table 3 ). There were no statistically significant differences in the VAS scores and in the proportion of patients who required rescue analgesics during the study period between the $\mathrm{P} / \mathrm{R}$ and $\mathrm{S} / \mathrm{R}$ groups (Table 4 ).
Table 4. Pain Intensity and Analgesics Used Postoperatively

\begin{tabular}{lccc}
\hline & $\begin{array}{c}\text { S/R group } \\
(\mathrm{n}=31)\end{array}$ & $\begin{array}{c}\text { P/R group } \\
(\mathrm{n}=31)\end{array}$ & P value \\
\hline $\begin{array}{l}\text { During 0-1 h } \\
\text { Pain intensity }\end{array}$ & $3.27 \pm 0.96$ & $3.07 \pm 1.20$ & 0.417 \\
$\begin{array}{l}\text { Analgesics used postoperatively } \\
\text { Tarasyn }\end{array}$ & $11(35.5 \%)$ & $8(25.8)$ & 0.412 \\
$\quad \begin{array}{l}\text { Pethidine } \\
\text { During 1-24 h }\end{array}$ & $2(6.5 \%)$ & $1(3.2 \%)$ & 0.557 \\
$\begin{array}{l}\text { Pain intensity } \\
\text { Analgesics used postoperatively } \\
\text { Tarasyn }\end{array}$ & $1.90 \pm 0.79$ & $2.11 \pm 0.76$ & 0.399 \\
$\quad$ Pethidine & $12(38.7 \%)$ & $15(45.2 \%)$ & 0.446 \\
\hline
\end{tabular}

The values are shown as means \pm SD or number of patients. There were no significant differences between groups.

\section{Discussion}

In this study, the Rhodes Index including the occurrence score, distress score and experience score was significantly lower in the $\mathrm{P} / \mathrm{R}$ group compared to that in the S/R group during the study period, and the incidence of complete response was significantly higher in the $\mathrm{P} / \mathrm{R}$ group compared to that in the $\mathrm{S} /$ $\mathrm{R}$ group. Also, the proportion of patients who required rescue antiemetics was significantly lower in the $\mathrm{P} / \mathrm{R}$ group compared to that in the $\mathrm{S} / \mathrm{R}$ group, during the first 1 hour after surgery.

The cause of PONV is probably a multifactorial origin. The risk factors include patient-related factors such as gender, nonsmoking status, past history of motion sickness and/ or previous PONV, surgical anesthesia technique, and postoperative pain [7]. Since vomiting after middle ear surgery may be due to increased pressure in the middle ear [18], we did not use nitrous oxide, which would increase the pressure in the middle ear. Rhodes and McDaniel [17] developed the Index of Nausea and Vomiting (INV) to capture the multidimensional features of upper gastrointestinal distress. The Rhodes Index was tested and found to be a valid and reliable instrument for measuring upper gastrointestinal distress. In the present study, the Rhodes Index was used instead of a simple numeric rating scale to measure the efficacy of TIVA with propofol and remifentanil.

There is now strong evidence that volatile anesthetics are emetogenic and that there are no meaningful differences between halothane, enflurane, isoflurane, sevoflurane, and desflurane in this respect [9]. A number of treatments have been introduced in order to reduce PONV after middle ear surgery, such as $\mathbf{5}-\mathrm{HT}_{3}$ antagonists, dopamine receptor antagonists, and antihistamine drugs. However, each of these treatments is associated with critical limiting factors, namely cost with $5-\mathrm{HT}_{3}$ antagonists, extrapyramidal symptoms with dopamine receptor antagonists and excessive sedation, and tachycardia with 
antihistamine drugs [19-21]. In patients at high risk for PONV, it would therefore make better sense to avoid inhalational anesthesia rather than simply to add an antiemetic [8,9].

In this study, the incidence and severity of PONV was significantly lower in the group that received TIVA with propofol and remifentanil compared to the group that received sevoflurane and remifentanil, during the first 24 hours after surgery. Also, the proportion of patients that required rescue antiemetics was significantly lower in the group that received TIVA with propofol and remifentanil compared with the group that received sevoflurane and remifentanil, during the first 1 hour after surgery. These results were in agreement with previous studies $[12,22]$. It has been reported that maintenance of anesthesia with sevoflurane results in a higher incidence of nausea and vomiting compared with propofol in a standardized outpatient population [22]. Also, Ionescu et al. [12] has reported that compared with isoflurane, total intravenous anesthesia (TIVA) with propofol and remifentanil resulted in a significantly lower incidence of PONV during the first 24 hours after surgery. However, Tramer et al. [13] following a meta-analysis of the literature, found that TIVA with propofol, rather than inhalation anesthesia, may have a clinically relevant effect on PONV but only in the short term. In addition, White et al. [14] reported that because TIVA reduced the predicted rate of PONV in the early postoperative period only, a long-acting antiemetic drug might be necessary to prevent postdischarge nausea and vomiting in day-case surgery. It has been shown that a minimum plasma concentration of propofol is necessary to produce an antiemetic effect [23]. Since propofol has a short, context-sensitive half-time (less than $40 \mathrm{~min}$ for infusions up to $8 \mathrm{~h}$ ), significant plasma-levels would be unlikely after several hours. As a result, propofol may need to be considered a prophylactic option for early PONV only. However, other factors that have been associated with PONV include type of surgery, choice of opioid, patient-age, and length of surgery [24,25]. Therefore, this discrepancy could be due to the differences in the protocol, patient characteristics and surgery.

Also, postoperative pain affects the incidence of PONV after surgery [7]. The total dose of remifentanil during anesthesia was significantly higher in the $\mathrm{P} / \mathrm{R}$ group compared to that in the $\mathrm{S} /$ R group $(1,210.94 \pm 439 \mu \mathrm{g}$ and $882.74 \pm 437 \mu \mathrm{g}$, respectively) but there were no statistically significant differences in the VAS scores and in the proportion of patients who required rescue analgesics during the study period between the two groups.

In this study, the Rhodes Index was significantly lower in the $\mathrm{P} / \mathrm{R}$ group compared to that in the $\mathrm{S} / \mathrm{R}$ group, during the first 24 hours after surgery. Also, the proportion of patients who required rescue antiemetics was significantly lower in the $P / R$ group compared to that in the $\mathrm{S} / \mathrm{R}$ group, during the first 1 hour after surgery.
Interpretation of our findings should be considered within the context of the limitation of the study. Firstly, the sample size of the study was relatively small despite a sufficient number of patients per the results of the power analysis. Secondly, we did not include high-risk patients with a history of motion sickness, or a previous episode of PONV in our study. Future researchers should take these limitations into consideration.

In conclusion, compared to balanced anesthesia with sevoflurane and remifentanil, TIVA was followed by significantly lower incidence and severity of PONV. This result suggests that TIVA with propofol and remifentanil may be a useful anesthetic approach for the reduction or prevention of postoperative nausea and vomiting after mastoidectomy with tympanoplasty.

\section{References}

1. Golembiewski J, Chernin E, Chopra T. Prevention and treatment of postoperative nausea and vomiting. Am J Health Syst Pharm 2005; 62: 1247-60.

2. Macario A, Weinger M, Truong $P$, Lee $M$. Which clinical anesthesia outcomes are both common and important to avoid? The perspective of a panel of expert anesthesiologists. Anesth Analg 1999; 88: 1085-91.

3. Honkavaara P. Effect of ondansetron on nausea and vomiting after middle ear surgery during general anaesthesia. Br J Anesth 1996; 76: 316-8.

4. Fujji Y, Toyooka H, Tanaka H. Granisetron in the prevention of nausea and vomiting after middle ear surgery: a dose-ranging study. Br J Anaesth 1998; 80: 764-6.

5. Jung JS, Park JS, Kim SO, Lim DG, Park SS, Kwak KH, et al. Prophylactic antiemetic effect of midazolam after middle ear surgery. Otolaryngol Head Neck Surg 2007; 137: 753-6.

6. Fujii Y. Clinical strategies for preventing postoperative nausea and vomitting after middle ear surgery in adult patients. Curr Drug Saf 2008; 3: 230-9.

7. Watcha MF, White PF. Postoperative nausea and vomiting. Anesthesiology 1992; 77: 162-84.

8. Apfel CC, Kranke P, Katz MH, Goepfert C, Papenfuss T, Rauch S, et al. Volatile anaesthetics may be the main cause of early but not delayed postoperative vomiting: a randomized controlled trial of factorial design. Br J Anaesth 2002; 88: 659-68.

9. Apfel CC, Stoecklein K, Lipfert P. PONV: a problem of inhalational anaesthesia? Best Pract Res Clin Anaesthesiol 2005; 19: 485-500.

10. Hogue CW Jr, Bowdle TA, O'Leary C, Duncalf D, Miguel R, Pitts M, et al. A multicenter evaluation of total intravenous anesthesia with remifentanil and propofol for elective inpatient surgery. Anesth Analg 1996; 83: 279-85.

11. Larsen B, Seitz A, Larsen R. Recovery of cognitive function after remifentanil-propofol anesthesia: a comparison with desflurane and sevoflurane anesthesia. Anesth Analg 2000; 90: 168-74.

12. Ionescu D, Mărgărit S, Vlad L, Iancu C, Alexe A, Deac D, et al. TIVATCI (Total IntraVenous Anesthesia-Target Controlled Infusion) versus isoflurane anesthesia for laparoscopic cholecystectomy. Postoperative nausea and vomiting, and patient satisfaction. 
Chirurgia (Bucur) 2009; 104: 167-72.

13. Tramer M, Moore A, McQuay H. Propofol anaesthesia and postoperative nausea and vomiting: quantitative systematic review of randomized controlled studies. Br J Anaesth 1997; 78: 247-55.

14. White H, Black RJ, Jones M, Mar Fan GC. Randomized comparison of two anti-emetic strategies in high-risk patients undergoing daycase gynaecological surgery. Br J Anaesth 2007; 98: 470-6.

15. Marsh B, White M, Morton N, Kenny GN. Pharmacokinetic model driven infusion of propofol in children. Br J Anaesth 1991; 67: 41-8.

16. Minto CF, Schnider TW, Egan TD, Youngs E, Lemmens HJ, Gambus $\mathrm{PL}$, et al. Influence of age and gender on the pharmacokinetics and pharmacodynamics of remifentanil. I. Model development. Anesthesiology 1997; 86: 10-23.

17. Rhodes VA, McDaniel RW. The Index of Nausea, Vomiting, and Retching: a new format of the Index of Nausea and Vomiting. Oncol Nurs Forum 1999; 26: 889-94.

18. Perrault L, Normandin N, Dlamada L. Middle air pressure variations during $\mathrm{N}_{2} \mathrm{O}-\mathrm{O}_{2}$ anaesthesia. Can Anaesth Soc J 1992; 29: 428-32.

19. Fujji Y, Tanaka H, Kobayashi N. Prevention of nausea and vomiting after middle ear surgery: granisetron versus ramosetron. Laryngo- scope 1999; 109: 1988-90.

20. Fujji Y, Toyooka H, Tanaka H. Prophylactic antiemetic therapy with a combination and dexamethasone in patients undergoing middle ear surgery. Br J Anaesth 1998; 81: 754-6.

21. Barann M, Göthert M, Fink K, Bönisch H. Inhibition by anaesthetics of 14C-guanidinium flux through the voltage-gated sodium channel and the cation channel of the 5-HT3 receptor of N1E-115 neuroblastoma cells. Naunyn Schmiedebergs Arch Pharmacol 1993; 347: 125-32.

22. Raeder J, Gupta A, Pedersen FM. Recovery characteristics of sevoflurane- or propofol-based anaesthesia for day-care surgery. Acta Anaesthesiol Scand 1997; 41: 988-94.

23. DeBalli P. The use of propofol as an antiemetic. Int Anesthesiol Clin 2003; 41: 67-77.

24. Gan TJ. Risk factors for postoperative nausea and vomiting. Anesth Analg 2006; 102: 1884-98.

25. Gupta A, Wu CL, Elkassabany N, Krug CE, Parker SD, Fleisher LA. Does the routine prophylactic use of antiemetics affect the incidence of postdischarge nausea and vomiting following ambulatory surgery? A systematic review of randomized controlled trials. Anesthesiology 2003; 99: 488-95. 